\title{
Risk and Vulnerability in the Analysis of Apartment Buildings
}

\author{
Ana Maria Grămescu, Mihaela Pericleanu, Dan Pericleanu and Răzvan Dimofte
}

\begin{abstract}
The real estate funds in Romania in the category of condominiums presents an important subject to be analyzed after several considerastions. Securing apartment buildings raises issues of high complexity. The present study focuses on the presentation of the criteria of analisys, the earthquake as a degradation factor of these buildings, the evolution of norms regarding seismic actions concluding with an important study case building - the Simu apartments block in Bucharest. The authors also synthesized information from several publications over time in Romania.
\end{abstract}

Keywords - earthquake, reinforced concrete, risk, vulnerability

\section{INTRODUCTION}

The existing real estate fund in Romania in the category of condominiums presents a wide variety of styles, architectural and structural concepts, and can be analyzed after several considerations: construction period, seismic design code and execution rules followed, architectural, functional and structural type, regime height, terrain and site characteristics.

Securing apartment buildings raises issues of high complexity in adopting effective solutions to eliminate the cause of degradation or uncontrolled intervention. This procedure requires a detailed knowledge of the design and implementation characteristics.

Recently, there has been a lot of talk internationally about progressive collapse. All over the world, constructions face a degree of continuous depreciation generated, in addition to meteorological phenomena, and the rather rapid evolution of technology, technical prescriptions and regulations, the impact of constructions with destructive chemical, physical, mechanical factors, the human factor through a series of actions such as: lack of maintenance and quality work performed on time, interior changes of apartments, etc.

There has been a lot of talk lately about the progressive collapse. In this sense, a definition provided in the American code ASCE 7-05 is formulated as follows: "the spread of the initial local damage from element to element, resulting in the failure of the whole structure or a large part, disproportionate from it". Progressive collapse is used to describe the spread of the initial local damage, in a manner analogous to a chain reaction, which leads to the partial or local collapse of a structure. The basic characteristic of progressive collapse is the final stage of failure, it is disproportionately higher than the failure that initiated the collapse of resistance to progressive collapse of structures, but within the standard for the calculation of accidental actions SR EN 1991-1-7: 2007 is defined the term robustness as "the ability of a structure to withstand events such as fires, explosions, 
impacts or the consequences of human error, without being disproportionately affected by the original cause".

The causes of the initial damage may be natural (eg wind gusts, floods, fires, strong earthquakes, etc.) or human (eg explosions, terrorist bombings, vehicle impact, etc.) as shown in Fig.1, Fig. 2, Fig. 3, Fig. 4 or Fig. 5. These types of loads that may or may not occur during the lifetime of a construction are called accidental, catastrophic, or extreme loads. The Romanian design code CR0-2012 defines the term accidental action as "action of short duration, but of significant intensity, for which there is a low probability of being exercised on the structure during its projected lifetime". Even if the progressive collapse is a rare occurrence, it is necessary that the structures be designed so as to withstand the action of such accidental loads.
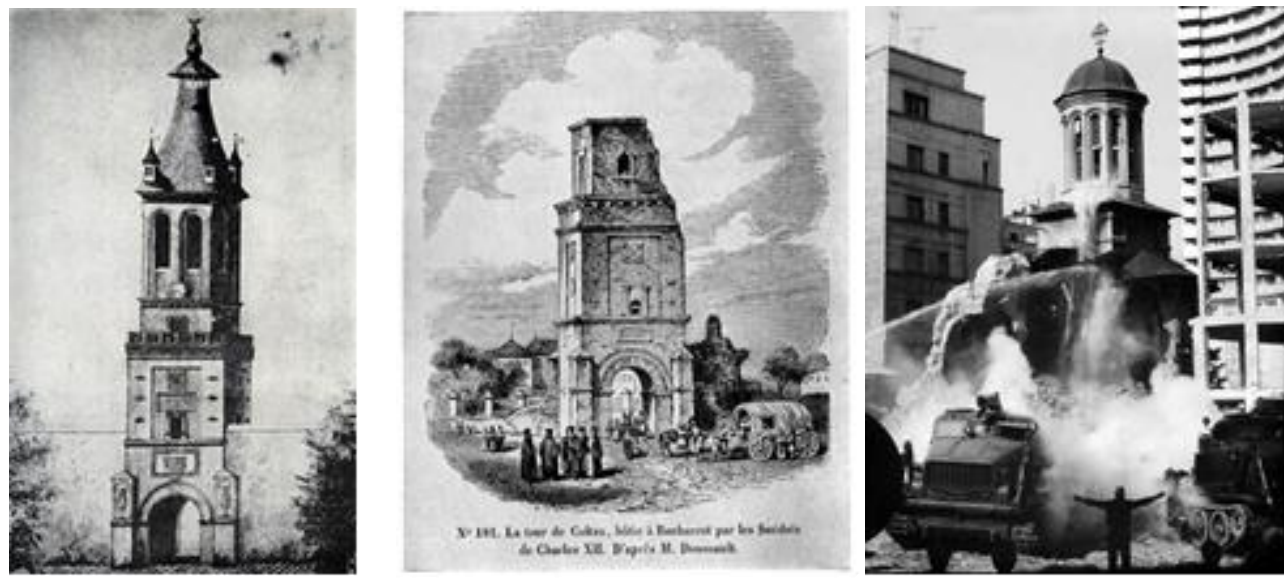

Fig. 1. The effects of the 1940 earthquake
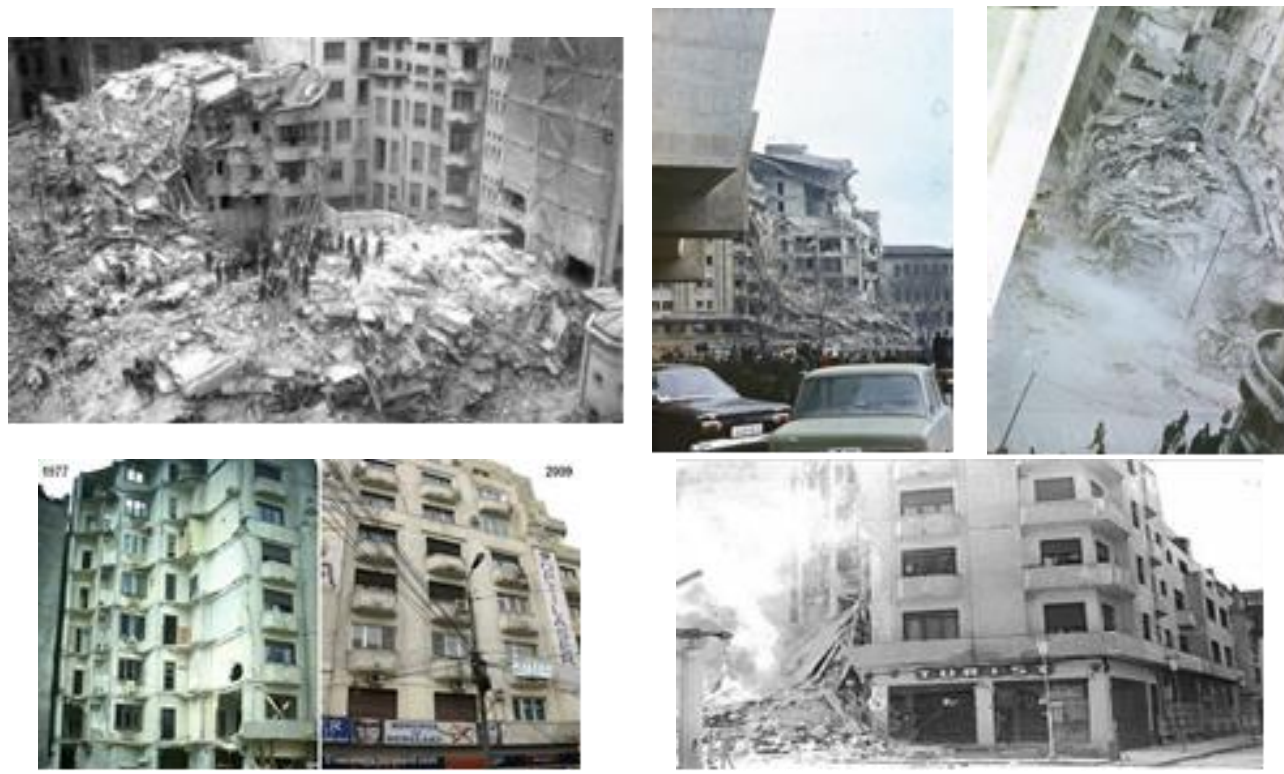

Fig. 2. The effects of the 1970 earthquake 


\section{sciendo}
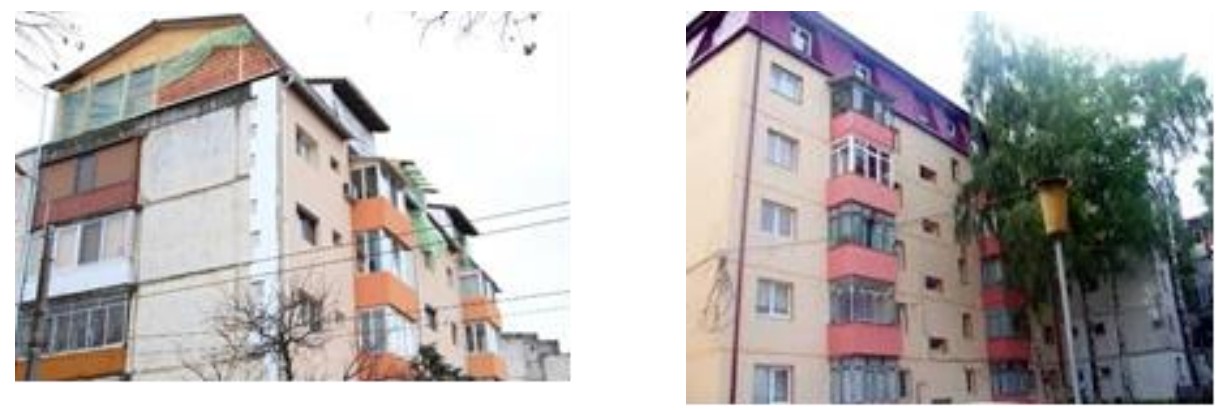

Fig. 3. Attic of the apartment blocks - presentation of inaccuracies

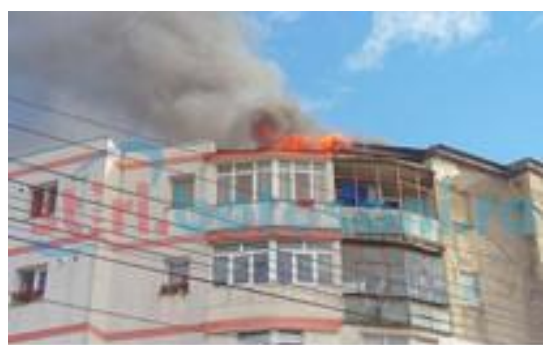

Attic fire - wood components without fireproofing

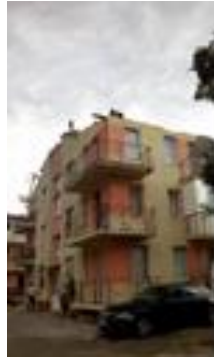

Roof shattered by the wind

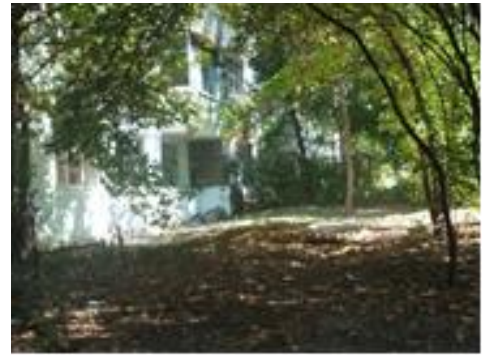

Subsidence of an apartment block in Galați

Fig. 4. Examples of degradation to block buildings

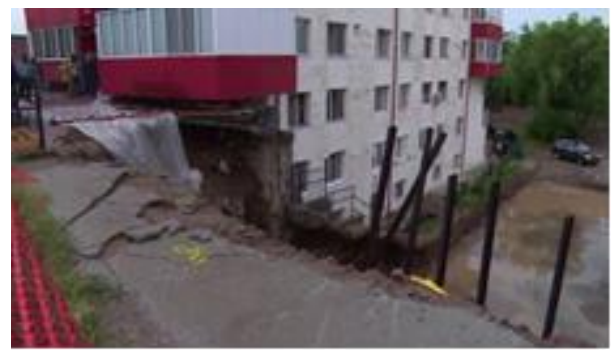

Groundwork collapsed on a length of 70 meters on the Lugoj - Deva highway

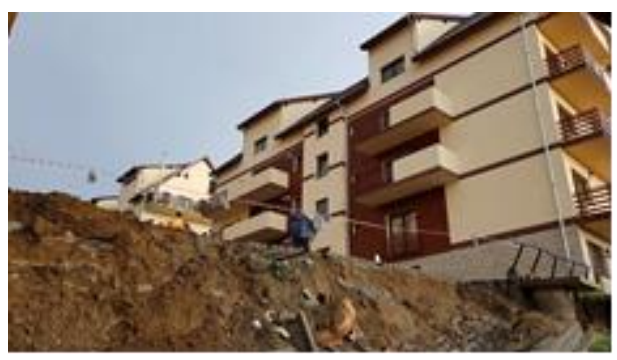

Landslide near an block apartments in Sibiu

Fig. 5. Examples of degradations related to land movements

\section{PRESENTATION OF CHARACTERISTICS CONSTRUCTION SOLUTIONS}

Residential buildings are classified by structure type and year of construction in Table 1 , according to information from the last census in 2011.

The allocation made by the National Institute of Statistics is approximate because the real number of buildings with prefabricated reinforced concrete structure is considerably smaller. It is a common practice among city dwellers to consider a block of prefabricated facade panels as a fully prefabricated.

Also, the statistical analysis by type of floor is uncertain because there are many cases of old buildings where there are partially reinforced concrete floors, usually in the area of bathrooms, hallways and stairs, and the rest are made of wood. The use of a wooden floor 
above the last level was a common solution in interwar life and is still the case today in individual house type buildings

Table 1. Distribution of residential buildings by strength structure and year of construction

\begin{tabular}{|c|c|c|c|c|c|c|}
\hline \multicolumn{2}{|c|}{ Building structure } & $<\mathbf{1 9 1 9}$ & $\mathbf{1 9 1 9 - 1 9 4 5}$ & $\mathbf{1 9 4 6 - 1 9 6 0}$ & $\mathbf{1 9 6 1 - 1 9 7 0}$ & $\mathbf{1 9 7 1 - 1 9 8 0}$ \\
\hline \multirow{2}{*}{$\begin{array}{c}\text { Reinforced } \\
\text { concrete }\end{array}$} & Monolith & 1319 & 2171 & 4027 & 11791 & 15568 \\
\hline $\begin{array}{c}\text { Masonry } \\
\text { with floors } \\
\text { from: }\end{array}$ & $\begin{array}{c}\text { Reinforced } \\
\text { concrete }\end{array}$ & 30279 & 73374 & 139032 & 217243 & 105910 \\
\cline { 2 - 8 } & 10811 & 29788 & 61718 & 105320 & 84154 \\
\hline \multicolumn{2}{|c|}{ Wotal } & 50624 & 114913 & 224639 & 249400 & 97334 \\
\hline \multirow{2}{|c|}{} & $\mathbf{2 4 4 3 1 8}$ & $\mathbf{6 1 4 9 9 1}$ & $\mathbf{1 2 2 4 1 3 7}$ & $\mathbf{1 3 0 8 5 2 9}$ & $\mathbf{4 9 8 5 9 3}$ \\
\hline
\end{tabular}

\begin{tabular}{|c|c|c|c|c|c|c|}
\hline \multicolumn{2}{|c|}{ Building structure } & $\mathbf{1 9 8 1 - 1 9 9 0}$ & $\mathbf{1 9 9 1 - 2 0 0 0}$ & $\mathbf{2 0 0 1 - 2 0 0 5}$ & $\mathbf{2 0 0 6 - 2 0 1 1}$ & Total \\
\hline \multirow{2}{*}{$\begin{array}{c}\text { Reinforced } \\
\text { concrete }\end{array}$} & Monolith & 15734 & 5771 & 4362 & 7807 & 68550 \\
\hline $\begin{array}{c}\text { Masonry } \\
\text { with floors } \\
\text { from: }\end{array}$ & $\begin{array}{c}\text { Refabricated } \\
\text { concreed }\end{array}$ & 63070 & 88097 & 62178 & 112687 & 891870 \\
\cline { 2 - 8 } & 59530 & 91348 & 61162 & 118677 & 623308 \\
\hline \multicolumn{2}{|c|}{ Total } & 44734 & 52095 & 23391 & 35061 & 892131 \\
\hline
\end{tabular}

\section{EVOLUTIONARY ANALYSIS OF TECHNICAL PRESCRIPTIONS}

In order to understand correctly, the situation of the urban real estate fund in Romania, it is necessary to understand the evolution of the design regulations after the major earthquake of 1940 and to know the history.

In 1941, after the earthquake, the first design instructions appeared based on foreign rules called provisional instructions, being approved on December 30, 1941. These were revised in 1945 becoming permanent instructions, approved on May 19, 1945. In these instructions, the seismic force is considered equal to $5 \%$ of the resultant of gravitational forces, evenly distributed, on the height of the building, at the floors level.

From the point of view of structural engineering, according to the seismic design code used, there are five types of buildings, according to the HAZUS methodology and the proposals of professors Lungu and Dubină in Table 2:

Table 2. Evolution of technical prescriptions

\begin{tabular}{|c|c|c|c|}
\hline & Period & Code level & Indicative \\
\hline I. & $\begin{array}{c}<1940 \\
1941-1963\end{array}$ & Pre-code & \\
\hline II. & $1964-1977$ & Inferior code & $\begin{array}{l}\mathrm{P} 13 / 1963 \\
\mathrm{P} 13 / 1970 \\
\end{array}$ \\
\hline III. & $1978-1992$ & Moderate code & $\begin{array}{l}\mathrm{P} 100 / 1978 \\
\mathrm{P} 100 / 1981\end{array}$ \\
\hline IV. & $1992-2013$ & Good code & $\begin{array}{l}\mathrm{P} 100 / 1992 \\
\mathrm{P} 100 / 2006\end{array}$ \\
\hline V. & 2013 & Advanced code & P100/2013 \\
\hline
\end{tabular}




\section{sciendo}

154 Ovidius University Annals Series: Civil Engineering, Year 23, 2021

The evolution of the distribution and intensity of the seismic design forces on the Romanian territory, according to the Seismic Design Norms and Codes):

- The conditioned norm for the design of civil and industrial constructions from seismic regions P13-63, with the seismic zoning map in STAS 2923-63 [2];

- Seismic design standard P 13-70, with seismic zoning map in STAS 2923-63 [3];

- Seismic design regulations P 100-78 (81), with seismic zoning map in STAS $11100 / 1-77$ [4], [5]

- Seismic design regulations P 100-92 (96), with their own zoning maps [6];

- Seismic design codes P 100-1 / 2004 (2006), with their own zoning maps;

- Seismic design code P 100-1 / 2006, with their own zoning map;

- Seismic design code P 100-1 / 2013, with their own zoning map;

- Seismic design code P 100-1 / 2019, with their own zoning map

The regulations developed and applied in buildings design before 1989 were aligned with the CAER documents and were oriented towards severe material and workmanship savings. The regulations developed and implemented after 2000 are in line with similar documents in the EU and are mainly based on the concept of "seismic performance".

The research project aims to perform a comparative analysis of the evolution of seismic design principles, how these measures are found in the structural analysis of constructions in frames made over time, which were the effects of previous seismic actions on them, how to intervene for elimination of defects, as well as proposing a structural analysis procedure for each of the buildings made in different seismic areas.

\section{METHODS OF STRUCTURAL ANALYSIS}

Structural analysis methods aim at in-depth analysis of intervention methods and proposals for assessing the degree of vulnerability of reinforced concrete buildings in frames according to the analyzed criteria, destructive factors, working procedures of a reinforced concrete building according to the period of execution, by the norms that were the basis of its design and execution - the procedures being developed within the three stages: analysis, diagnosis and intervention. As is well known, the factors influencing the increased risk of reinforced concrete frame structures are:

- Design errors; Execution errors;

- Meteorological phenomena;

- Chemical, biological attack, the action of repeated vibrations;

- Unauthorized construction interventions;

- Lack of timely and quality maintenance work;

- Improper exploitation of the building;

- The evolution of functional impairments and the influence of the human factor;

- Functional changes affecting the strength structure;

- Seismic action;

- Fire action;

- Differentiated subsidence;

- Lack of legislation depending on the operation of the condominium;

- Lack of education in construction field for all categories of staff contributing to the quality of buildings throughout life;

- The evolution of technical prescriptions and normative acts in the field that contribute to the quantification of a different degree of risk in a structural analysis - and the lack of involvement in ensuring an adequate structural response of the existing built fund (wind, snow, seismic action, etc.). 


\section{CASE STUDY}

The building that is the subject of the case study is known as the "SIMU block" or the LIDO block located in Bucharest adjacent to Franklin Street and Anastasie Simu Street as well as Magheru Blvd., it was built based on a design project from 1933 (as it results from the resistance memoir regarding the restoration of the collapsed staircase after the earthquake) but also from the existing documents in the design project and which were part of the Building Permit. Following the 1977 earthquake, the wing from Franklin Street and partially Magheru Blvd collapsed - respectively the B staircase collapsed (Fig. 9), producing other collateral structural depreciations (Fig. 10). Subsequently, this section of the building was rebuilt, the reconstruction and consolidation project being carried out by the Bucharest PROJECT Institute.

The construction in question, - block of apartments with commercial spaces on the ground floor of staircase B with height regime $\mathrm{Ug}+\mathrm{Gf}+7 \mathrm{~F}-$ was made in monolithic reinforced concrete frames with monolithic reinforced concrete floors, dimensioned according to DIN 1045 - valid German technical prescriptions at the date of the execution of the construction, respectively the year 1933, prescriptions appeared in the specialized literature in 1932 translated by university professor Phd. eng M Hanganu.

The building was designed to have a basement, ground floor of which part of it located towards Tache Ionescu Blvd. (Anastasie Simu Street) was provided with housing (staircase A) and the other part towards Franklin Street and Magheru Blvd. with commercial spaces, the height of this ground floor being over $5.5 \mathrm{~m}, 6$ floors of apartments and the 7th floor, where there were common spaces and for serving some apartments, all arranged on 3 buildings, which were reached through a central hall, with access from Anastasie Simu Street (except for the shops that had independent street access) - (from the consultation of the registration in the land book from 1940.

The building in question had and still has facades on 3 streets. As mentioned above, most of the ground floor has been reserved for shops. Thus, according to the 1933 plan drawn up for the building permit on the ground floor of the block on the side from Take Ionescu Blvd, there are entrances to 5 stores and in addition to these you can find another store with an orientation towards Metropolitan Saguna Street (later renamed Tache Ionescu and A Simu street) and one to Franklin Street (according to the annexes of the report of technical expertise) in total 7 stores.

The resistance structure of the building was designed from monolithic reinforced concrete frames, made of reinforced concrete columns, beams and floors. The "filling between the columns" as recorded in the written pieces (partition walls) was made of thin hollow brick masonry on the outside and solid brick on the inside (according to documents studied in the archive). The resistance memoir drawn up in 1978 with references to the building to be rebuilt / consolidated referred to the data resistance structure given below.

According to the memoir prepared after the event (Earthquake of 1977) on the occasion of the restoration of the collapsed area of the block section - staircase B - Design Institute - BUCHAREST PROJECT - records: "the rupture took place on the line separating the apartments without affecting the staircase A", but generally affecting the strength structure, partition walls, facade and finishes. In the same document, in the resistance memoir it is specified: "The structure of the building before the earthquake was a unit made of monolithic reinforced concrete, with monolithic reinforced concrete floors and brick walls with holes in the facade and full at the blind wall with $28 \mathrm{~cm}$ thickness. Inside the masonry was generally $7 \mathrm{~cm}$ thick executed with solid brick or gaps outside the walls bordering staircase A which was $14 \mathrm{~cm}$ made of solid masonry". 


\section{sciendo}

156 Ovidius University Annals Series: Civil Engineering, Year 23, 2021

The Land Book Documentation drawn up in 1940 under no. 9028, records in the description of the building the fact that:

The basement has 5 cellars with a closet of the respective shops, 23 cellars, a garbage crematorium room, a mechanic's room, a radiator room, a toilet, a shower room, three laundries, two dryers and two ironers.

According to the same memoir from the Land Book drawn up in 1940 under no. 9028, the ground floor of the building is composed of 5 shops, each with a room, a studio and an apartment.

In 1959, according to the documentation sent by the Housing and Real Estate Records Service under no. 22748 / 4.07.2017, documentation submitted as a result of the expert's request to study the state lease contracts for commercial spaces, the issuer states that they do not have the leases of the commercial spaces related to the period prior to the 1977 earthquake, but with this answer are attached two plans at 1/50 scale that contain the basement and ground floor plan from 1959, plans that highlight the following aspects:

- According to the documentation sent by the Housing Fund and Real Estate Records Service under no. 22748 / 4.07.2017 which presents the situation in 1959, the 5 stores with entrances from Take Ionescu Blvd. together with the two ones from Franklin and A. Simu street were transformed into three stores with much more generous areas store 1 with an area of $86.32 \mathrm{sqm}$; store 2 with an area of $26.90 \mathrm{sqm}$ (which can be appreciated as having the initial opening but no changes are recorded in the rear area, stairs, doorman cabin) and store 3 with an area of about $74 \mathrm{sqm}$, areas that were obtained by demolition of the wall from axis 2 , axis 4 , axis 5 , and in axis 4 it was possible that the brick wall was replaced with a glazing or other variant recorded in the dimensions of the plan (as it appears in the photographic images after the earthquake).

- The changes in the 1959 plans for the reconfiguration of the found stores (but it is not known when exactly it was intervened but it is certain that until the date of drawing up these plans) led to changes in the ductility of the ground floor structure, its rigidity with major repercussions regarding the behavior in seismic actions, an aspect that we will develop in the following.

The image of the building from 1964 (Fig. 6) - In the facade on the ground floor you can see the existence of withdrawals of the entrances to the shops from the front of the first row columns. (Florin Erimia "A Dark Window" - Polirom Publishing House).

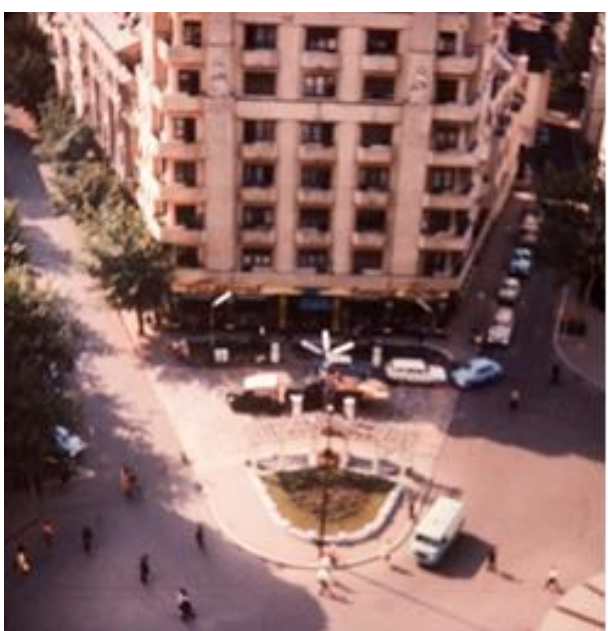

Fig. 6. Image from 1964 - there were already changes to the ground floor of the block by demolishing some filling walls (1933 plans compared to 1959) 
During the 1977 earthquake, the wing from Franklin Street with commercial spaces on the ground floor and 6-room apartments on each floor collapsed.

Also in the memoir of the design project for the restoration of the collapsed staircase structure drawn up by the Bucharest Project in 1978, in the presentation of the degradations it is noted that in addition to the collapse of the section were also registered: "ruptures, fractures and displacements, dislocations of masonry, fracture of columns and beams from Franklin Street", as well as:

- Existence of poor quality concrete (not proven by research activity and laboratory tests);

- Lack of stirrups at the base of the columns on the ground floor and at the node of the floor beams;

- Segregation areas in the concrete of the columns;

- Strong cracking of the floors above the ground floor in the shop area and cracks of the floors above the first floor up to the 6th one, in the space adjacent to the collapsed area;

- The real lack of embedding of the columns at the level of the floor above the basement - but, this argument is not argued with any evidence.

- The important size of the beams section in the shop area with a much higher rigidity than the columns, but this statement is not proven by the explanation of the geometric structure.

The designer engineer states in the memoir of the technical design project for the restoration of the fallen section about the fact that these statements set out above are not proven / supported by the stripping of all the columns.

In the conclusion of these expositions, the last paragraph, it is noted that based on the performed analyzes, the cause of the partial collapse of the building is the very low rigidity of the construction due to the small cross-sections of the construction elements and the small dimensions and densities of the partitions walls, which created the favorable conditions for breaking the latter.

The difference in rigidity presented by the construction in question was caused by:

- In the area of staircase A with houses on the ground floor and masonry the rigidity is higher, compared to that of staircase B which had a high ground floor which in 1933 was provided with filling walls by the compartmentalization of the 5-7 stores, but which later, so as the ground floor plan appears in 1959, it was transformed into a space with much less masonry arranged between the construction frames due to reconfiguration by creating larger spaces, reducing the number of stores in favour of surplus space for reorganized stores;

- Lack of analysis and repercussions by the beneficiary of these interventions. According to the specialized literature, the calculation of the resistance structures in reinforced concrete frames at the level of the years 1030-1940 was done with the contribution of these filling walls. Therefore, even if the commercial space is reconfigured, intervention measures should be considered on the respective areas to ensure the replacement of the rigidity provided by the walls that were demolished.

Also in this memoir prepared in 1978, it is noted that the filling walls were $7 \mathrm{~cm}$ and $14 \mathrm{~cm}$ of solid masonry next to the separation plane between building staircase A and B (Fig. 7), and that there are reduced rigidities of the ground floor among other causes.

The architectural elements that make this block special are the two ornaments on the main facade - Fig 8. Only one original ornament has been preserved, the one on the right, in art-deco style. This represents the modernist muse of inspiration, who leans on the Simu block, of which only a part can be seen. The remade one represents an athlete in a T-shirt and shorts, holding a hammer in his hand. There is an obvious stylistic difference between the two ornaments. 

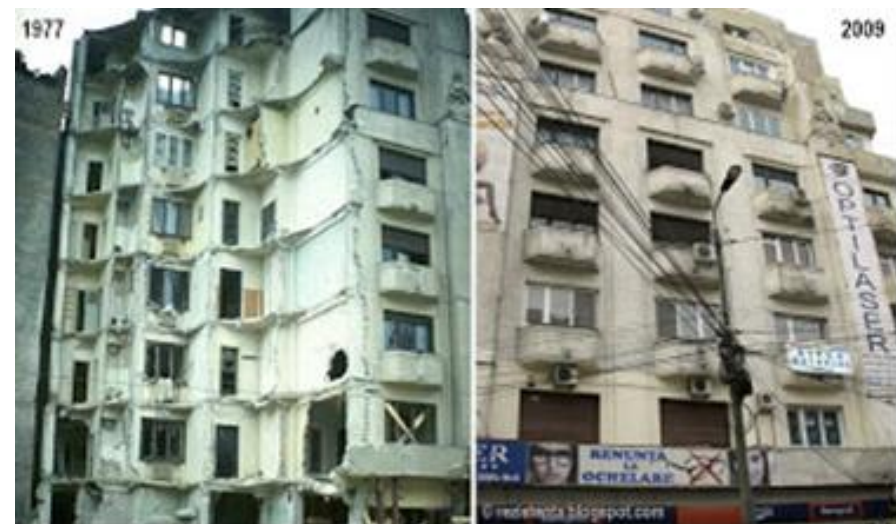

Fig. 7. Image immediately after the earthquake and right with the ladder rebuilt

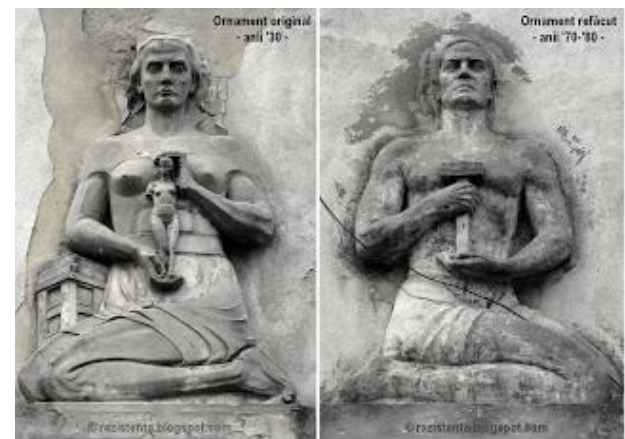

Fig. 8. Image with the ornaments from the facade

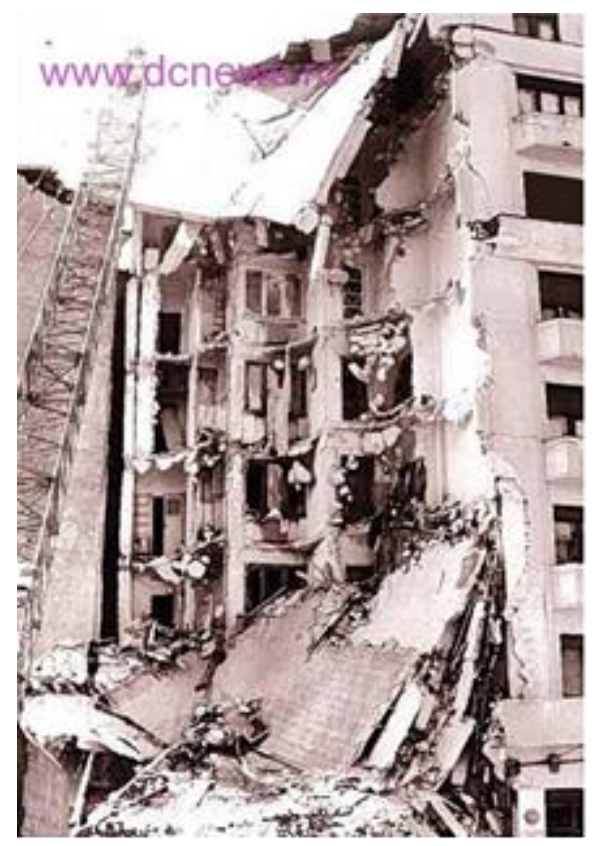

Fig. 9. Image after the earthquake before the debris area was released 


\section{sciendo}

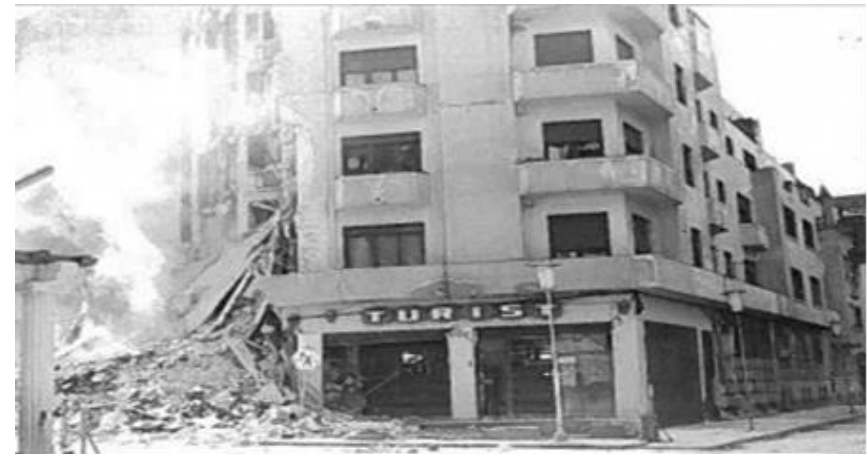

Fig. 10. Formation of plastic joints at the top of the columns on the ground floor - image after the earthquake

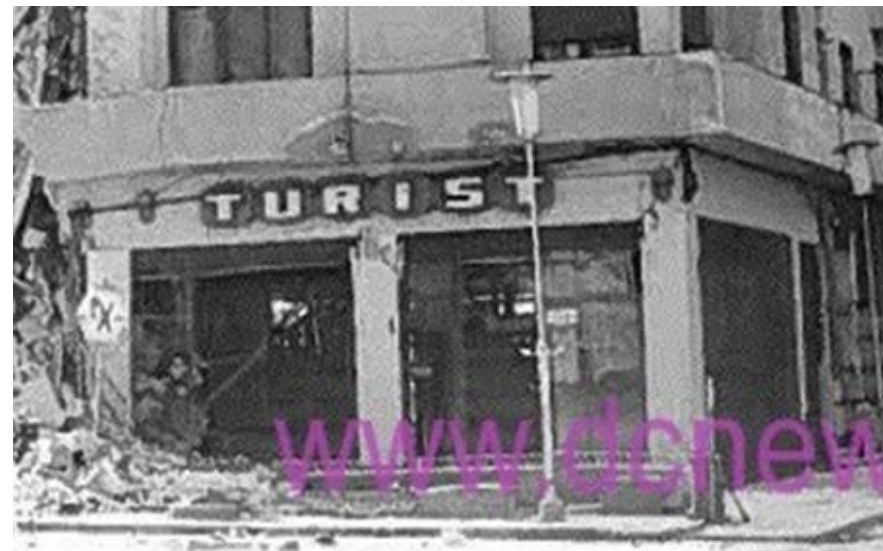

Fig. 11. Detail. Plastic joints at the top of the ground floor column

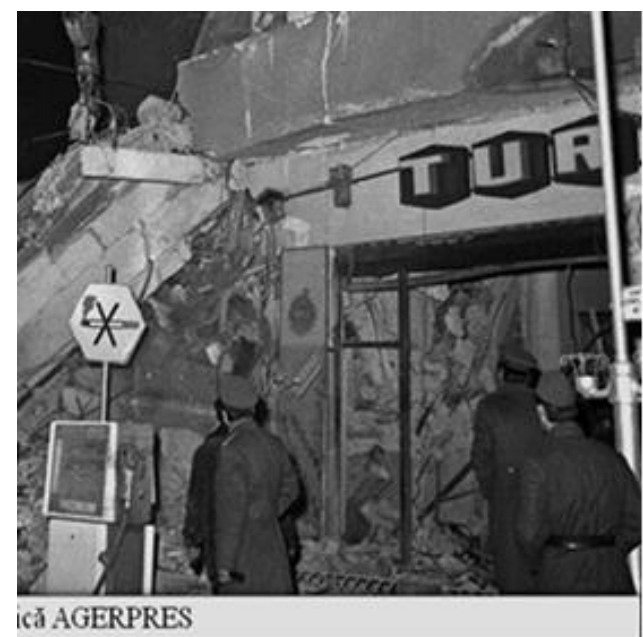

Fig. 12. Detail the area between the former store 3 and 4 from the drawings from 1933 . The image of the detached materials visible in this axis highlights the lack of a wall and the maximum existence of a glazing without structural connection with the frame columns 


\section{sciendo}

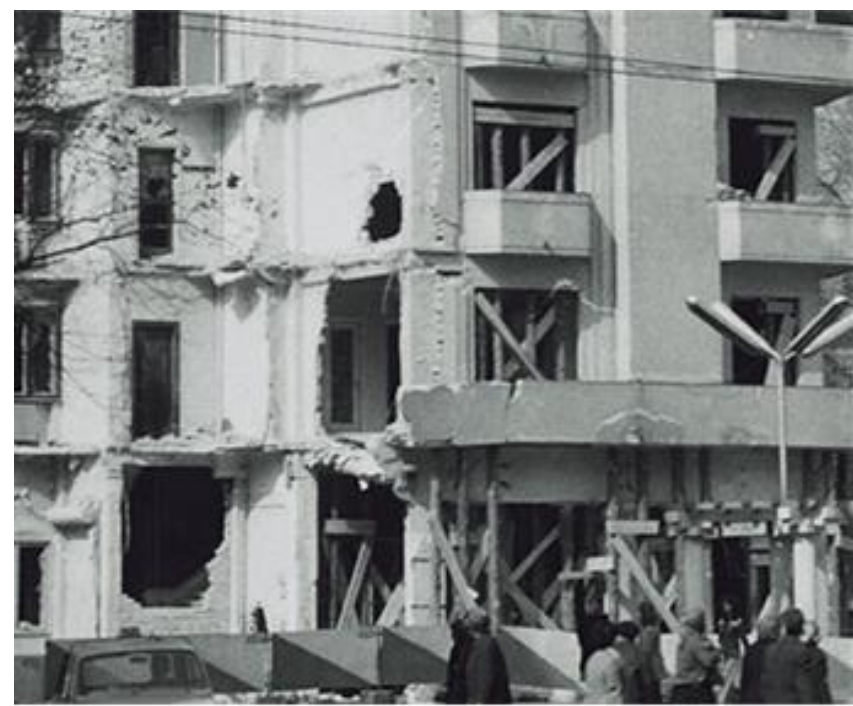

Fig. 13. Image after the earthquake, after the assembly of the debris and the support of the ground floor at which in the facade columns next to the former shops 4, 5, 6 have the appearance of plastic joints at the top of the columns. It can be seen on the 1 st and 2 nd floor the collapse of the walls in the axis of separation of the two sections - the collapsed and the remaining one. The solid masonry is embedded in the resistance structure

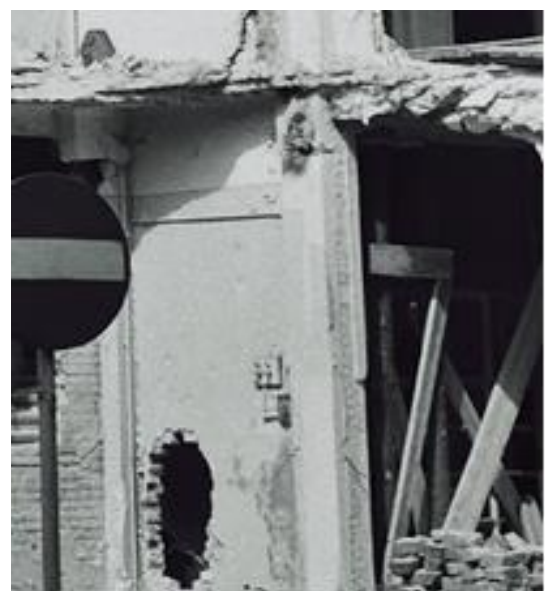

Fig. 14. Detail of the ground floor area between the former store 3 and 4 according to the 1933 plan

The image in Fig. 12, Fig. 13 and Fig. 14 shows the column of the corresponding axis between the store 4 and 3 - axis that shows no signs of detachment of the partition wall aspect that claims that the commercial spaces at the time of the earthquake had been reconfigured from the project situation where it is clearly identified a number of shops with their own cellars, an aspect also found in the drawings made in 1959 and sent by the Housing Fund and Real Estate Records Service under no. 22748 / 4.07.2017 - at the request of the technical expert. The same image as on the ground floor cannot be seen on the $1 \mathrm{st}$ floor where the way of yielding the wall between section A and B is highlighted - Fig 15 . 


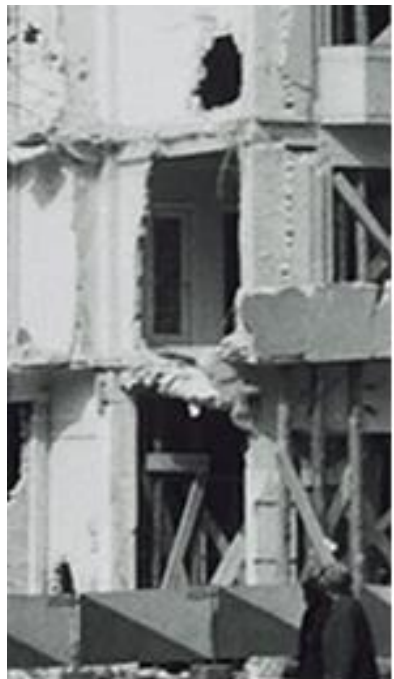

Fig. 15. Image with the yielding wall

At the date of the earthquake - you can see the shop window on the background (further behind the façade) compared to the columns of the building in front. This observation is not accompanied by another written argument or another clear picture - a fact which will not be taken into account in the scientific interpretation of the behavior of the section of the building collapsed during the 1977 seismic action.

The specialized literature notes overall that degradation of apartment blocks after the 1977 earthquake that were partially collapsed as well as apartment blocks that were damaged but didn't collapsed they are of the nature of degradation in columns, beams and less common in floors.

The specialized literature regarding the behavior of the constructions in general at the action of the 1977 earthquake records that the main causes of the inappropriate behavior of the buildings are:

- Unordered shapes of blocks;

- Low reinforcement percentages;

- Failure to achieve spatial rigidity due to lack of collinearity of structural elements;

- Misalignments or second order supports of the beams;

- Insufficient number of stirrups in the extreme areas of the columns;

- Insufficient reinforcement length of the reinforcements in the columns which were calculated only at fundamental loads;

- Causes related to the execution process;

- Causes related to exploitation (changes to the resistance structures, partitioning, removal of the partition walls arranged between the columns - aspects that led to the increase of the flexibility of the columns and to the yielding in the areas of joint with beam - Fig VI. 21 page 248 from the paper Earthquake in Romania from March 4, 1977 written by acad. Stefan Balan, eng. Valeriu Cristescu and PhD. eng Ion Cornea in Bucharest Academy Publishing House - 1982 [14] where is presented even a frame node from the ground floor identified by the authors right at the section of the block that is the object of the study case);

- The high frequency of degradations was registered when the beams were supported on the columns in case of the removal of some partition walls in order to create larger spaces - especially in the structures where the ground floor is commercial and has a 
higher height than the rest of the block. In such situations, no measures were made to compensate for the rigidity, practically the resistance reserve given by the well-spread partitioning masonry between the sides of the frame columns was eliminated by demolishing these walls in order to achieve wider spaces.

In an earthquake of the intensity and duration of the one of 1977 - a strong earthquake - a structure in reinforced concrete frames makes incursions in the inelastic field - fact for which a construction must have a sufficient capable ductility.

Ductility is a very important criteria, representing the post-elastic deformation capacity of the structure.

Another element is the rigidity of the structure - rigidity and ductility being two interdependent criteria.

An equally important element that greatly influences the behavior of a construction in an earthquake and the two criteria set out above is the interaction between the reinforced concrete frames and the partition walls (filling). The so-called partition walls, even when made of low thickness but made of brick filled with cement mortar and well anchored to the structure, lead to limited displacements and improved behavior of the structure of reinforced concrete frames to seismic actions - even more so as the frames / columns may not have had sufficiently dense stirrups at the ends (but this aspect is not highlighted by a test / proof). The partition walls arranged between the faces of the columns and made correctly of solid masonry take over the effects of the displacements of the structure on the respective level, limiting the relative displacement of the level working in solidarity with the elements of the frames.

Also in the paper "Seismic Engineering" coordinated by Prof. PhD. Eng. Negoita Al Didactic and Pedagogical Publishing House 1985 in chapter 10.5 [21] it is noted that during an earthquake, the filling walls can have a positive influence on the strength and stability of a building.

Also in this publication [21], page 370 records the following aspects related to structures similar to the building in question:

"in the case of constructions in frames and filling masonry, a series of important damages appeared, sometimes even the collapse of some constructions, due first of all to the very high intensity of the earthquake of 4/03/1977, which led to much higher demands than those provided. In calculations and secondly due to the failure to take into account, accordingly, the frame-masonry assembly of the filling that cooperates in the action of the horizontal loads. The filling walls can create vertical stiffness discontinuities (especially for constructions with commercial spaces on the ground floor), pronounced asymmetries in the plan, reducing the working length of columns and beams, etc ... in the blocks without compartments on the ground floor the columns of the ground floor were severely damaged immediately below the floor, and the second block with partitions on the ground floor structure was not affected at all instead all the walls on the ground floor were severely degraded".

During an earthquake in the non-structural elements arranged between the elements of a frame, deformation forces can appear which lead to the cracking of the masonry panel (usually after the two diagonals), but - at the same time this deformation of the filling / compartmentation wall saves the deformation state of the reinforced concrete frames, of the nodes, ensuring a higher rigidity and contributing to the limitation of the relative level movement. In these cases, the non-structural elements dissipate a significant amount of energy introduced by an earthquake in a building, thus saving the skeleton of resistance the frames. The masonry takes over part of the stress-induced state of seismic motion (SB Smith's hypothesis regarding the cooperation between masonry and reinforced concrete frame elements applies). The length of the contact areas between the masonry and the 
reinforced concrete elements on which the width of the equivalent diagonal depends (hence the rigidity) varies as a ratio between the rigidity of the masonry and the frame structure. Therefore, the partitioning masonry - the non-load-bearing walls contribute to the increase of the level rigidity.

Stiffness discontinuities occur especially in the case of free ground floor - ground floor with commercial space - when the structure transforms into a structure with weak columns and strong beams - in which case the construction structure has a low energy absorption capacity in the area of maximum seismic stress. This case is also specific to the building in question, which due to the demolition of the partition walls, the building had an energy absorption capacity induced by an earthquake but diminished compared to the initial situation.

We find this behavior in the building in question where the percentage of walls compared to 1933 when there were 7 shops was reduced in time (highlighted in 1959) on the ground floor or low thickness, which prevented the rotation of the nodes. In this case the plastic joints were formed on the columns at the extremities as can be seen in the image below.

On page 370 [21], the last paragraph records "for the blocks without compartments on the ground floor, the columns of the ground floor were severely damaged at the extremities".

Also in the publication book "Seismic Engineering" authors Al Negoita s.a., paper published by the Romanian Academy in 1986 presents the following schemes of efforts in different stages of an earthquake (Fig. 16, Fig. 17, Fig. 18 and Fig, 19):

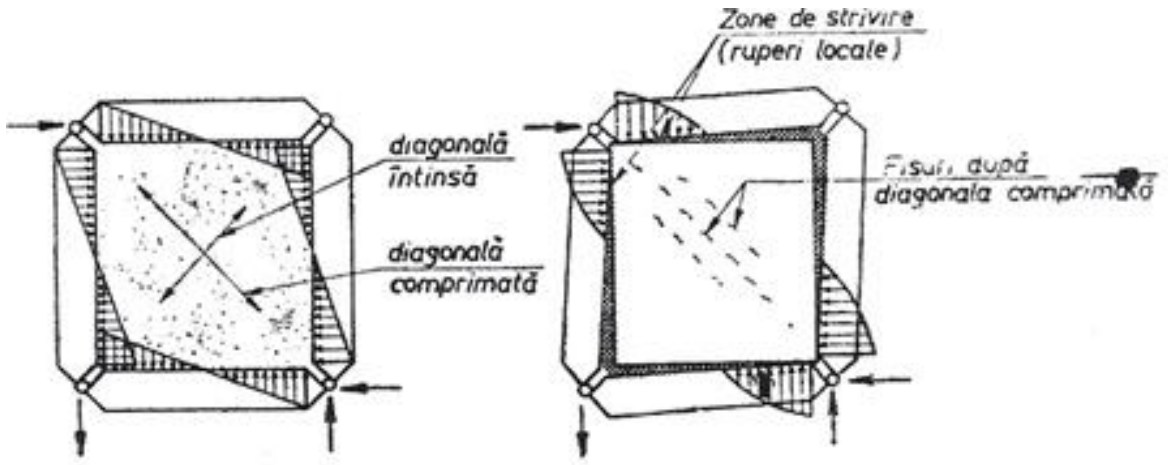

Fig. 16. a (10.41) The state of efforts in the filling wall in the elastic stage / b (10.42) The state of efforts in the filling wall after the elastic stage [21]
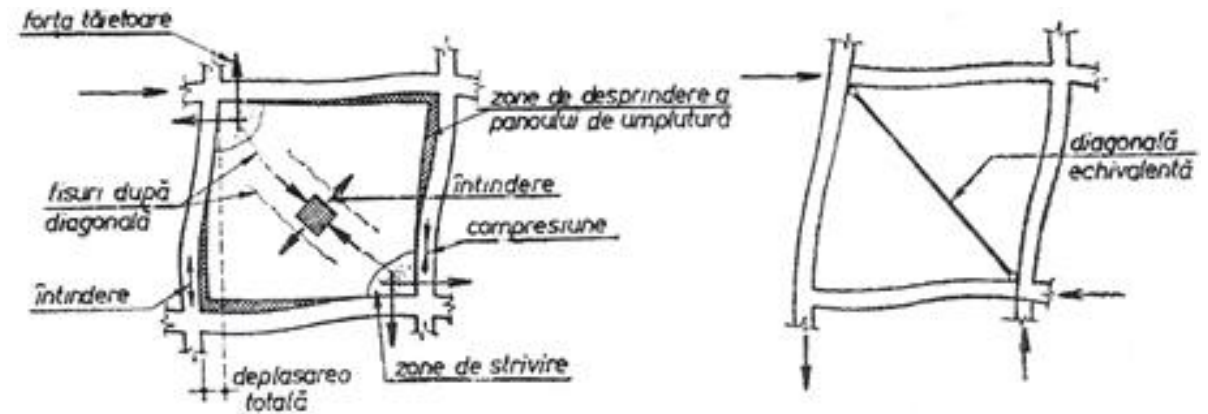

Fig. 17. Interaction between the frame and the filling walls [21] 


\section{sciendo}

164 Ovidius University Annals Series: Civil Engineering, Year 23, 2021
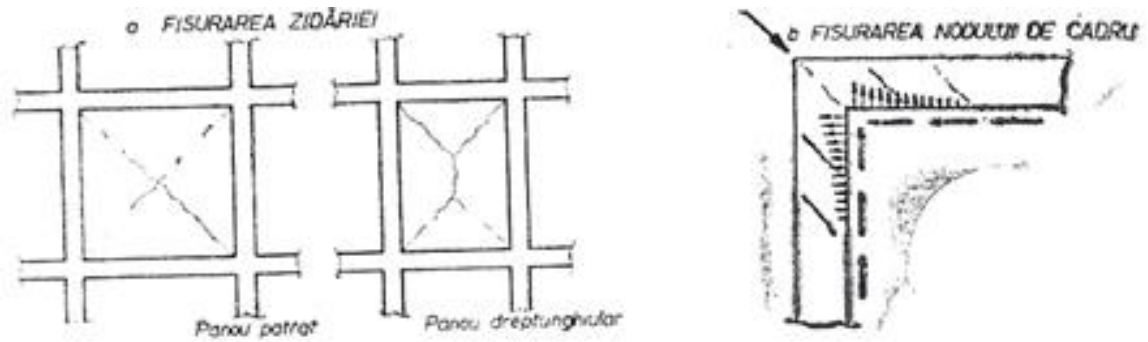

Fig. 18. Cracking of the frame-wall assembly due to the action of horizontal loads[21]
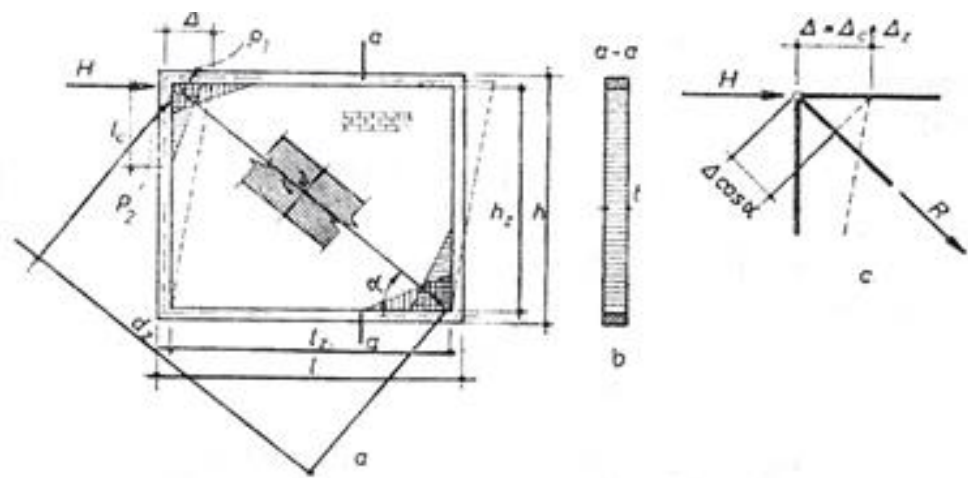

Fig. 19. Establishing the contact areas between the frame and the filling masonry [21]

Changing the distribution of rigidities (either by demolishing some walls, drilling holes in vertical or horizontal elements) to a structure entails the variation of rigidities, a particularly important factor in changing the response of a structure to seismic actions, motivated by the fact that this is one of the factors. which modifies the intensity of seismic forces [7] (Mihail Ifrim - the published book "Dynamic analysis of structures and seismic engineering" published in Didactic and Pedagogical Publishing House 1973 chapter 9 page 273. This change can be caused by decommissioning of non-structural elements, partitioning walls made of masonry well positioned between the frame elements or not, drilling holes in walls or floors for various purposes, functional reconfiguration by moving partition or structural walls to a load-bearing masonry building - measures for which if the repercussions are not analyzed with the adoption of corrective intervention measures may have important behavioral effects, especially during seismic actions. These effects are caused by the situation in which the center of rigidity does not coincide with the point of application of the total lateral force in the plane of each floor, there are moments of torsion that substantially change the distribution of lateral force to the vertical elements.

Demolition of the partition walls between the columns of a frame when the frames are not completely separated from the calculations (provided with appropriate rigidity and ductility) leads imminently to changes in the rigidity of the structure, to the appearance of additional displacements on that level where the measures were taken. We find this situation in the constructions made mainly before 1950 (constructions in which the partition walls were well positioned between the columns of the frames, made with solid brick, but it is also notorious that also in the old constructions the ground floor with commercial destination had a big height compared to the rest of the floors and the free columns (with decommissioned partitions) were vulnerable to deformations caused by seismic actions. These interventions diminish the relative rigidity of the level. 
In a multi-storey structure, in reinforced concrete frames, the relative level rigidity is the ratio between the floor shear force and the relative displacements between levels in this case, the floor shear force being calculated by reporting the 1st floor load with the weight of structural elements up to $1 / 2$ of the height of the 1 st floor and $1 / 2$ of the height of the ground floor.

In the work Concepts and energetic methods in construction dynamics, author Sanda Hangan and Liviu Crainic published in the Romanian Academy publishing house in 1980, in chapter 13.3 .3 page 274 the associative contribution between frames and filling walls is recorded. The filling wall prevents the free deformation of the frame, forcing it to behave similarly to a lattice beam. At this stage, the wall is subjected to compression forces directed along the diagonal of the masonry panel and in the column elements, at the columns and beams, the predominant efforts are the axial ones. Once the masonry panel comes out of work, the shear force on the whole structure creates strong displacements and bending moments in the beams and columns. The subsequent increase of the lateral load can cause a new calculation scheme - the plasticization of either a masonry panel or an element of the frame structure.

Thus, in this building, the weights of the dividing walls between the stores, with their rigidity, did not intervene in this evaluation, which contributed to the modification of the rigidities to the detriment of the ground floor columns and to the formation of plastic joints at the top of the ground floor columns (Fig.11.) the relative rigidity of the columns in case the nodes translate to seismic action and the beams are more rigid - the floors being considered as infinitely rigid elements in the horizontal plane.

Partition walls have an important role in limiting displacements if they are made properly between columns and well positioned, with structural connections - if they are made of brick with quality mortar.

The references recorded in the documents regarding the masonry of the blind walls highlight these aspects. Not the same conclusions are kept in walls compartments made of glazing, gypsum or other materials. Brick masonry confers a behavior that influences the behavior of reinforced concrete frames by its ability to cope with incursions generated by seismic movements through the ability to deform, take over displacements and deformations on diagonals and finally materialized by cracking it after the two diagonals but in exchange with the service of limiting the displacements of the fulfilled frame columns.

In the present situation, the documents studied regarding the configuration of the construction in 1933 show that on the ground floor with a height of more than $5 \mathrm{~m}$ there were 7 stores - nominated with $1 \ldots .5$ and two sides, they show that these stores were separated by compartmentalization wall elements because otherwise it was defined as a unitary commercial space (in the attached drawing that accompanies the urbanism certificate or the authorization the axes were drawn between the stores - there are no construction details for the block, especially for the ground floor). This statement is further supported by the 1933 plans that were the subject of the building authorization and also:

- Technical memoir with the description of the existing building at the Bucharest Land Book, no. 9028/1940);

- The basement floor and ground floor plans from 1959 which were subsequently submitted at the request of the expert and the lease contracts for the commercial spaces on the ground floor, contracts from which the leased areas were observed. Even if for this request it is sent by the address no. 22748 / 4.07.2017 that there are no documents from which to result the repartition of the basement and the ground floor starting with 1950 and until 1977. At the same time it is specified that there are no records of the Bucharest Real Estate Fund rental or spreadsheets for the property in question. 


\section{sciendo}

166 Ovidius University Annals Series: Civil Engineering, Year 23, 2021

The documents transmitted after by ICRAL Bucharest with the plans from the ground floor of the pre-built area highlight the fact that in 1959 there were 3 stores, one of which (axis 4) just the area of detachment from the section that withstood the earthquake has recorded the fact that there is only one metal frame - possibly a glass glazvand. This aspect is also highlighted by the detail in the photographic image where the face of the column can be seen without traces of masonry rupture as it appears in the rest and even the linear trace detached with the metal element (possibly also wood) expelled which had no connection with the column (if there was a structural connection, the area would appear with rough or signs of tearing).

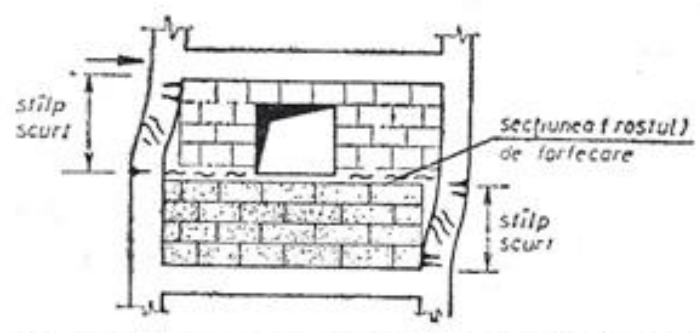

Fig. 10.47. Ruperea prin forfecare a zidăriei și transformarea stîlpilor in stilpi scurti prin discontinuitatea pe verticală a zidảriei.

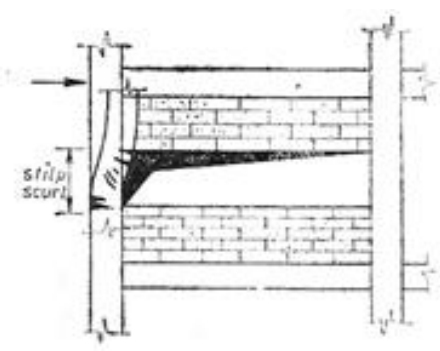

Fig. 10.48. Panouri de zidărie extinse numai pe o zonả și trans formarea stîlpilor în stîlpi scurti.

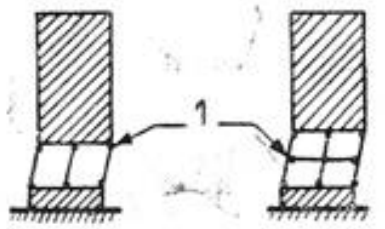

a
Fig. 10.49. Structură in cadre cu rigiditate variabilă pe ni= vele, datorită parterului liber:

- - fára pereti despartitori la un nivel ; $b$ - la doua nivele; 1 - articu-

Fig. 20. Details of masonry failure (10.47 - shearing of masonry and transforming the columns into short columns by masonry vertical discontinuity; 10.48 - masonry panels extended only over one area and transforming the columns into short columns; 10.49 -

structure in frames with variable rigidity on levels caused by the free ground floor)

In the case of ductile frames, they are designed with appropriate rigidities, capable of withstanding incursions in the elastic and plastic field, having the capability that the appearance of plastic joints cannot be irreversible. In any case, the ductile frame implies the acceptance of the formation of plastic joints on the beam, namely in directed areas, so that the state of stress and tension of the structural element is minimal.

Additional measures belong to the frames where the ground floor is flexible from a functional point of view but also structurally and the floors behave as a unitary whole, motivated by the fact that the floors between the floors made of reinforced concrete are

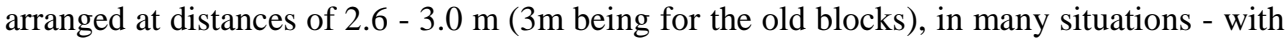
solid brick masonry walls, well positioned between the elements of the frames, as it happens on the area of the blind walls (Fig. 20).

On the ground floor, in the old apartment blocks with commercial spaces on the ground floor, the height level of the ground floor is over 5.4 meters and due to the fact that the height is higher the rigidity remains a measure that is complemented by other structural 
measures, such as partition walls. Made of solid brick masonry, well positioned and anchored between the elements of the frames. In this situation, the filling walls are an important element in limiting the relative level displacements and quantifying the stiffness. Their abolition contributes to the decrease of ductility and to the appearance of additional bending moments, even of the torsional moments.

The specialized literature develops this concept - an example in the work "Design of reinforced concrete structures for seismic actions" by Thomas Paulay published in the Technical Publishing House in 1997, translated from German, shows especially, in structures in frames, the fact that the relation force - displacement on each level influences the inelastic dynamic behavior, dissipation of energy induced by an earthquake with the promotion of the Bauschinger effect, a phenomenon that occurs in the longitudinal reinforcement bars, in the area of plastic joints, leading to decreased stiffness causing a pinching of the curve of hysteresis. These effects are visible in the selected images on the internet, in the Simu block.

The relative floor displacements at the apartment block in question were amplified during the 1977 seismic movement due to the force-displacement ratio, the inelastic deformations being large. Therefore, in such a structure, on the area of floors 1-7, the maximum force-displacement effects can be neglected if the relative floor displacements do not exceed by $1 \%$ the height of the floor.

In the case of the free ground floor of the Simu apartments block, the freedom being caused by the demolition of some filling walls, including the one that separates store 3 from 4 , where the detachment of the B staircase and its failure occurred, the structure had a very important force-displacement ratio, because the displacement exceeded the relative displacement of the level related to the height of the ground floor of about 5.5 meters.

Based on these considerations, our personal opinion is that the presence of the filling walls, as the structure was designed in 1933, would have prevented the collapse of section $\mathrm{B}$, but it would have been damaged as recorded in the literature for similar structures, publication published after the 1977 earthquake and which highlights in addition to these global causes collapsed or damaged constructions and a number of other inaccuracies found in similar structures respectively: design deficiencies, deficiencies of execution concerning the poor quality of concrete or lack dense stirrups in some areas or effects of segregation.

For the Simu apartments block (Fig. 21, Fig. 22), it is difficult to invoke such issues listed in the previous paragraph, motivated by the fact that the parties did not submit elements that expressly certify these deficiencies, namely laboratory tests, photographic images of the ceded elements, the technical project with details of execution or a report made after the earthquake based on the analysis of the elements, their uncovering. In the present situation, there is only the technical memoir drawn up by the Bucharest Project Institute for the restoration of the collapsed section, a project which was drawn up in 1978 . Also in this technical memoir, the designer states that not all the elements were uncovered and makes a series of references regarding the structural composition before the event, references that are based on the initial design of the building. At the same time, the statements in the technical memoir prepared in 1978 regarding the quality of construction (concrete, reinforcement systems) are not accompanied by evidence.

The above-mentioned work, "Designing Reinforced Concrete Structures for Seismic Actions" by Thomas Paulay published in the Technical Publishing House in 1997 - on page 130 (Chapter IV, point 4.1.1) states "facade elements, partition walls and other nonstructural elements can significantly influence frames behavior". 


\section{sciendo}

168 Ovidius University Annals Series: Civil Engineering, Year 23, 2021

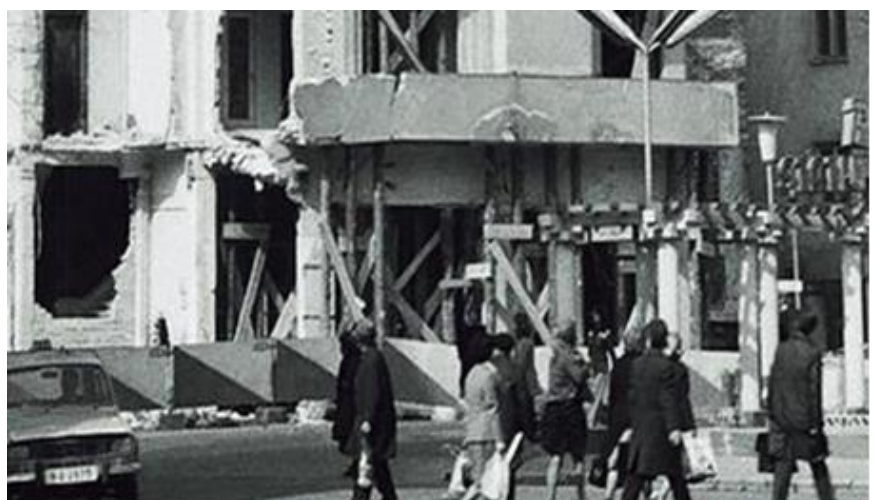

Fig. 21. Image from the Simu apartments block

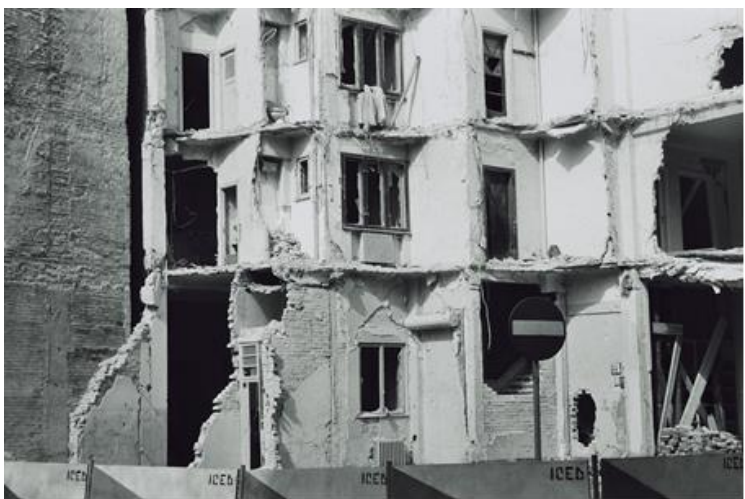

Fig. 22. Image from the Simu apartments block - a different view

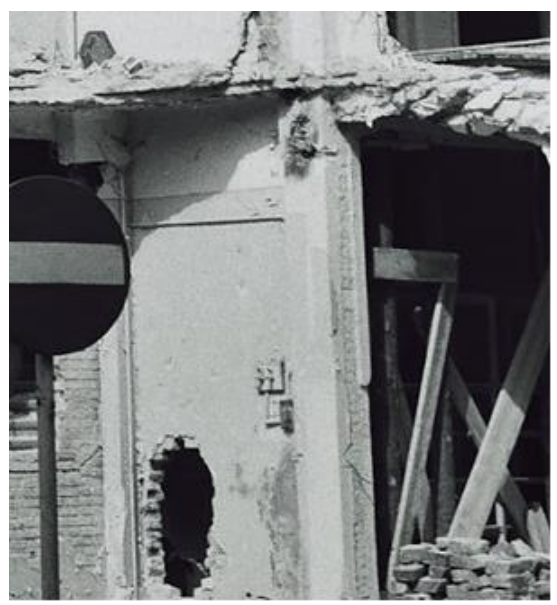

Fig. 23. Interior column detail between store 3 and 4 after the numbering in the 1933 Urbanism Certificate. It can be observed that the $14 \mathrm{~cm}$ solid brick wall was demolished (according to the 1959 plans provided by ICRAL Bucharest, this being replaced with a possible metal glazvand that had no structural connection with the column (otherwise there were visible anchors or tears). This column coincides with the plan of separation between staircase A and B, where the collapse of the staircase section occurred 


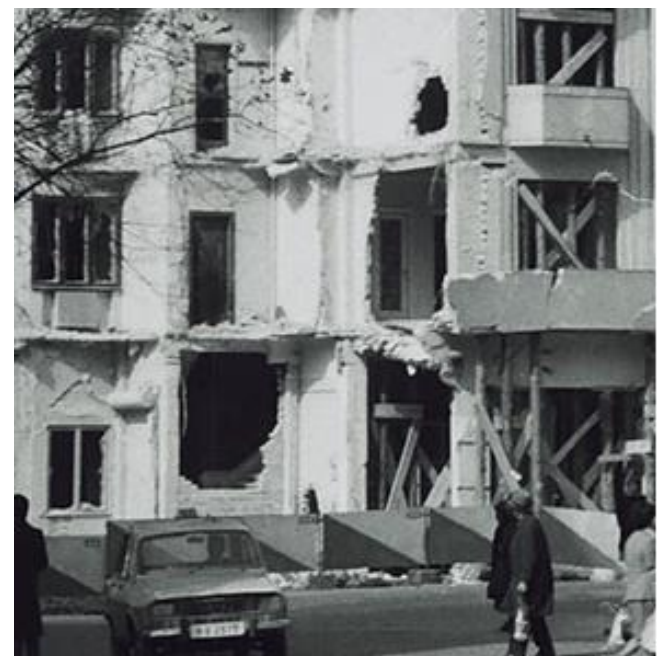

Fig. 24. Image from the Simu apartments block

In the publication Structural-non-structural relation in architectural design - author Mihaela Georgescu Ion Mincu University Publishing House 2006 - is recorded on page 214 the phrase "limiting the relative displacements of level by stiffening with the help of filling walls", if not designed by ductilization frame nodes. We must note that the problem of ductilization was introduced in the period 1950-1960 and widely debated in Liviu Crainuc's publication [22]. The situation of the section in question is obvious that until 1959 the refurbishment of the commercial space on the ground floor of the block was carried out by removing some filling walls that worked together with the frames of the ground floor, contributing to the limitation of relative level displacements.

In the work Accidents and damages in constructions - Sebastian Tologea Technical Publishing House 1980 develops this subject in chapter V - Earthquakes, where on page 148 he records the mechanisms of breaking the columns on the ground floor - visible in the area adjacent to the collapse of the section and the apartment block in question "the mechanism of breaking due to the lack of ductility " of the columns on the ground floor which were obstructed to limit the movement by removing the filling walls in order to achieve wider commercial spaces - without considering the fact that the columns are much higher than the height regime of the other levels with apartments and that the movements of the two components part and the area of the floors is different. Today, even if such homes are designed with a flexible ground floor intended for commercial spaces, the structures are provided with ductile nodes on the ground floor area - 1st floor, with measures to limit displacements (diaphragms, lamellar columns, etc.).

Also in the same publication on page 167 are recorded the general causes of accidents recorded in the 1977 earthquake and point 3 specifies: "subsequent transformations, especially on the ground floor of the apartment blocks made for various arrangements, recompartmental or modernizations, by removing some columns or walls that contributed to the decrease of the building's resistance capacity.".

In the work "Repair and consolidation of constructions" author A.M. Gramescu AGIR Publishing House in chapter 3 Behavior of constructions to seismic actions, as well as in the other chapters 4,5,6, are described examples of deficient behavior of constructions especially on the flexible ground floor with a high height regime compared to the other levels and it is noted that any removal of filling walls provided to work with the ground 


\section{sciendo}

170 Ovidius University Annals Series: Civil Engineering, Year 23, 2021

floor frames harms its rigidity, creates insufficient ductility and is an important factor in the poor response to seismic actions [25]. Even today, the introduction of filling walls is a method of stiffening the ground floor - as an intervention measure to improve behavior in seismic actions.

In the situation of the SIMU apartments block, the demolish of the filling walls contributed to the flexibility of the ground floor, leading to a deficient behavior in seismic actions (Fig. 23 and Fig. 24) - Dan Ghiocel - Civil Constructions, chapter 14 - 14.3.3, mixed structural systems - last paragraph of page 384 [24].

In the work - Reinforced concrete constructions - Ovidiu Marsu and Richard Friedrich - Didactic and pedagogical Publishing House Bucharest 1980 - it is recorded:

"we must remember the role of the anti-seismic diaphragm that the brick masonry walls inserted between the columns of the frames can have as possibilities for their ductilization. Brick masonry walls in a controlled or uncontrolled manner can interfere with the strength and stability of reinforced concrete structures subjected to strong earthquakes. Brick masonry is a fragile, rigid material with a high capacity for damping and energy absorption. With proper reinforcement, the brick masonry is transformed into a superior material, with ductility resistance, degradation stability and high energy absorption capacity. The masonry ductility will be more or less accentuated depending on the applied procedure.....

For multi-storey buildings with a structure in reinforced concrete frames with masonry filling subjected to seismic action, the diaphragm effect will be taken into account until the filling masonry comes out of work.....

According to the specialized literature, the filling masonry with the whole structural concept had to be taken into account in the analysis of the refurbishment of the ground floor of the Simu apartments block - respectively at the date of the recompartmentalization changes (they may have been made in stages but what is certain are the plans of 1933 and 1959 which do not correspond), motivated by the fact that in addition to the fact that it contributes to the increase of rigidity, it also has a significant contribution in limiting the displacements of the columns.

In the incursions of an earthquake, the masonry arranged between the frame elements is required for tension and compression, the maximum efforts appearing on the diagonals of the wall, the wall cracks but is a saving element of the frame.

During the earthquake, the ground floor behaves as a discontinuous effect of stiffness, the structure turns into a similar structure specific to weak columns and strong beams, at that time has a low energy absorption capacity, with destructive effects on the columns, defending the plastic joint either at the base or at the top of the columns on the ground floor area.

Therefore, the demolition of the filling walls in order to reconfigure the commercial spaces from the ground floor of the collapsed section was a technically unjustified measure, this contributing to the flexibility with the increase of the ground floor deformations, transforming the structure into a structure with variable rigidity free.

Always in the failure of a construction corroborates a set of determining factors, but one at a time may constitute or may create a deficient behavior in seismic action. The fact that a section did not collapse and the rest gave way to the 1977 earthquake - respectively staircase B this aspect substantiates the expert's opinion, supported by the opinions of other specialists expressed in the literature presented in this technical expertise report.

In the situation of the SIMU apartments block, the abolition of the filling walls on the area of the commercial spaces contributed to the flexibility of the ground floor, entailing a deficient behavior to seismic actions. 
Therefore, the demolition of the filling walls in order to reconfigure the commercial spaces on the ground floor of the collapsed section was a wrong measure, without considering remedial intervention measures (to replace the disused element), this contributing to flexibility with increasing ground floor deformations, transforming the structure into - a structure with variable rigidity on levels due to the free ground floor.

\section{CONCLUSIONS}

The analysis of the criteria for classifying collective constructions according to their structural characteristics can provide important, valuable elements in elucidating the following measures:

- Contributes to the establishment of the most efficient modern methods and techniques for consolidating structures in reinforced concrete frames:

- Allows the application of modern materials in consolidation solutions:

- Allows the establishment of criteria for analyzing their compatibility (longitudinal modulus of elasticity, transverse modulus of elasticity, Poisson's ratio, etc.);

- Contributions regarding the efficiency of the administration of the existing built fund;

- Contributions to the development of the technical framework of the design, execution and operation prescriptions;

- Contributions regarding the promotion of the condominium manual in the big urban centers in order to raise the awareness of the owners, tenants, administrators of the existing built fund;

- Development of the Romanian legislative base regarding the application of quality criteria in constructions, performance requirements, structural and functional safety of civil buildings.

\section{REFERENCES}

[1] I.L.Korcinski (1961), Seismic loads in construction. Guide for the application of the construction calculation method to seismic stresses, Technical Publishing House, Bucharest [2] P 13-63 (1964), Normativ conditionat pentru proiectarea constructiilor civile si industriale din regiuni seismice (Conditional regulation for the design of civil and industrial constructions in seismic regions), Technical Publishing House, Bucharest

[3] P 13-70 (1970), Normativ pentru proiectarea constructiilor civile si industriale din regiuni seismice (Norm for the design of civil and industrial constructions in seismic regions), Editorial office of construction publications, Bucharest

[4] P 100-78 (1978), Normativ pentru proiectarea antiseismica a constructiilor de locuinte, social-culturale, agrozootehnice si industriale (Norm for the anti-seismic design of housing, social-cultural, agro-zootechnical and industrial constructions), Incerc Publishing House, Bucharest

[5] P 100-81 (1981), Normativ pentru proiectarea antiseismica a constructiilor de locuinte, social-culturale, agrozootehnice si industriale (Norm for the anti-seismic design of housing, social-cultural, agro-zootechnical and industrial constructions), ICCPDC Publishing House, Bucharest 
[6] P100-91 (1991), Normativ pentru proiectarea antiseismica a constructiilor de locuinte, social-culturale, agrozootehnice si industriale (Norm for the anti-seismic design of housing, social-cultural, agro-zootechnical and industrial constructions), Bucharest

[7] Mihail Ifrim (1973), Analiza dinamica a structurilor si inginerie seismica (Dynamic analysis of structures and seismic engineering), Didactical and Pedagogical Publishing House, Bucharest

[8] Mihail Ifrim, Al. Dobrescu (1974), Aplicatii in analiza dinamica a structurilor si inginerie seismica (Applications in dynamic structure analysis and seismic engineering), Didactical and Pedagogical Publishing House, Bucharest

[9] Radu Priscu, Adrian Popovici, Dan Stematiu, Lucian Ilie, Constantin Stere (1980), Ingineria seismica a constructiilor hidrotehnice (Seismic engineering of hydrotechnical constructions), Didactical and Pedagogical Publishing House, Bucharest

[10] Radu Agent (1997/1998), Expertizarea si punerea in siguranta a cladirilor existente afectate de cutremur (Expertise and safety of existing buildings affected by the earthquake), Fast Print Publishing House

[11] S.T. Karapetrou, S.D. Fotopoulou, K.D. Pitilakis (2017), Seismic Vulnerability of RC Buldings under the Effect of Aging, International Conference on Sustainable Synergies from Buildings to the Urban Scale, SBE16, Aristotle University of Thessaloniki/ Department of Civil Engineering, Thessaloniki, Greece, Procedia Environmental Sciences 38 (2017) pg. $461-468$

[12] Edoardo Cosenza, Giorgio Monti (2009), Assessment and reduction of the vulnerability of existing reinforced concrete buildings, G. Manfredi, M. Dolce (eds), The state of Earthquake Engineering Research in Italy: the ReLUIS-DPC 2005-2008 Project, Doppiavoce, Napoli, Italy, pg. 51-110

[13] Andreea Dutu (2009), Analiza raspunsului seismic al cladirilor civile din beton armat reabilitate prin diferite metode modern de interventie (Analysis of the seismic response of civil reinforced concrete buildings rehabilitated by various modern methods of intervention), Construction, no. 2

[14] Anil K. Chopra, Rakesh K. Goel (2001), A modal pushover analysis procedure to estimate seismic demands for buildings: theory and preliminary evaluation, PEER Report 2001/03, Pacific Earthquake Engineering Research Center, College of Engineering, University of California Berkeley, January 2001

[15] Alex Horia Barbat, Ioana Olteanu, Mihai Budescu (2011), Sesimic vulnerability factors, International conference Deducon 70 - Sustainable development in construction, Iaşi, 11 november 2011

[16] Joseph Bracci, Sashi K. Kunnath, Andrei M. Reinhorn (1997), Sesimic performance and retrofit evaluation of reinforced concrete structures, Journal of structural engineering [17] Mario Lucio Puppio, Martina Pellegrino, Linda Giresini, Mauro Sassu (2017), Effect of material variability and mechanical eccentricity on the seismic vulnerability assessment of reinforced concrete buildings, Buildings, 7, 66

[18] Moldovan T. (2015), Studii privind efectul evolutiei normelor de proiectare seismica asupra vulnerabilitatii la colaps progresiv a structurilor in cadre din beton armat (Studies on the effect of the evolution of seismic design norms on the vulnerability to progressive collapse of structures in reinforced concrete frames), $\mathrm{PhD}$ thesis, Civil Engineering Faculty, Cluj-Napoca

[19] M Hangan (1932), Prescriptiunile Comisiunei germane pentru beton armat cu modificarile ulterioare (Requirements of the German Reinforced Concrete Commission with subsequent amendments) (translation eng M Hangan) 
[20] Stefan Balan, Valeriu Cristescu, Ion Cornea (1982), Cutremurul de pamant din Romania de la 4 martie 1977 (The earthquake in Romania on March 4, 1977), Bucharest Academy Publishing House

[21] Al. Negoita s.a. (1985), Inginerie Seismica (Seismic Engineering), Didactical and Pedagogical Publishing House, Bucharest

[22] Sanda Hangan, Liviu Crainic (1980), Concepte si metode energetice in dinamica constructiilor (Energy concepts and methods in construction dynamics), Romanian Academy Publishing House

[23] Mihai Ifrim (1973), Analiza dinamica a structurilor si inginerie seismica (Dynamic analysis of structures and seismic engineering), Didactical and Pedagogical Publishing House, Bucharest

[24] Dan Ghiocel s.a. (), Civil buildings

[25] AM Gramescu, D Barbu (2008), Repararea si consolidarea constructiilor (Repair and consolidation of constructions), AGIR Publishing House, Bucharest

[26] C. Mihai (1996), Noduri de grinda si stalp pentru structuri din beton armat (Beam and column knots for reinforced concrete structures), Technical Publishing House

[27] Emil Prager (1979), Betonul armat in Romania (Reinforced concrete in Romania), Technical Publishing House

[28] Image information on google maps

[29] Mass media 1977

[30] Dan Ionescu (2017), Revista CAPITAL 4.03.2017, 40 ani de la cutremur (40 years since the earthquake)

[31] Ana Maria Grămescu (2021), Raport de expertiză tehnică

Note:

Ana Maria Gramescu - Ovidius University of Constanta, Institute of Doctoral Studies, Bd. Mamaia nr. 124, 900356-Constanta, Romania (e-mail: am gramescu@ yahoo.com)

Mihaela Pericleanu - Ovidius University of Constanta, Faculty of Civil Engineering, Bd. Mamaia nr. 124 900356-Constanta, Romania (e-mail: pericleanu.mihaela@univ-ovidius.ro).

Dan Pericleanu - Ovidius University of Constanta, Faculty of Civil Engineering, Bd. Mamaia nr. 124, 900356-Constanta, Romania (e-mail: pericleanu.dan@univ-ovidius.ro).

Răzvan Dimofte - PhD, Ovidius University of Constanta, Faculty of Civil Engineering, Bd. Mamaia nr. 124, 900356-Constanta, Romania (e-mail: razvandimofte@ yahoo.com) 